\title{
日章丸における人間工学的研究
}

\author{
真辺春蔵*，難波精一郎*，吉田光雄* \\ 吉川敏枝*，黒田隆**，松木 哲**
}

We researched in the accomodations in the Oil Tanker, S. S. Nissho-Maru on the Persian Gulf Line. Results are as follows.

Illumination-levels at night in some rooms are lower than that of Japanese Industrial Standard. We can obtain standard levels of illumination by fluorescent lamps instead of incandescent lamps.

The color design of the accomodations in the ship provides comfortable visual environments.

Noise level in the ship was taken by the sound level meter and the fequency analyzer. On the other hand, sulyective estimations of the noise was given by means of Semantic Differential method and questionaire. As the result of these, it is sugested that below 60 phon (A) in the living rooms, below 80 phon (A) in the work areas may be desirable in the ship.

The atomospheric conditions of the living rooms are rather improved by the air conditioning, but in some work areas such as Engineroom and Galley it is so hot and urgent improvements are expected.

抄 録: 船舶の居住環境に関する人間工学的分析の一 環として，現在運航中のペルシャ涩航路大型タンカー日 鼻丸に乗船して各種の測定を行なった。結果は次の通り である。

照明：一般に夜間の人工照明による照度が低く, J I S の基準に達しないところが多い。これは白熱灯を 螢光灯に替えることによって照度をあげることが出来る ので改善は容易である。

色彩：船全体の色彩計画は優秀であって, 快適な視 覚環境を形成している.

騒音： 船内の騒音を騒音計, 周波数分析器等で测定 し騒音指数を算出すると共に S. D. 法, アンケート等に よって騒音に対する主観的評定を行なった結果，騒音計 の A 特性による測定值が S. D. 法による尺度值とよく対 応することが判明した. 本調査の結果から, 船舶騒音の

*大阪大学, Osaka University

**神戸商船大学 Kobe University of Mercantile Marine
許谷值として，居室は60ホン(A)以下，作業場では 80 ホ ン(A)以下を提案した.

温・湿度： ペルシャ湾航路における船内は高温であ り, 特に夏季においてその傾向は著しいが, 近年冷房設 備が設置されるようになり, 温・湿度の条件は公室のみ ならず，居室においても緩和されるようになった。しか し，作業区では必ずしも快適な作業環境とは云い難い. 例えば機関室, 調理室等は高温下での作業を余儀なくさ れている. 調理室は高温多湿である。これらの点で改善 の余地があると考えられる。

\section{1. 本研究の主旨}

\section{1-1. 研究の目的}

最近の海運産業の合理化によって船舶の自動化大型化 が急速に進み, そのため種々の心理的な問題が起こって 来た。すなわち， 

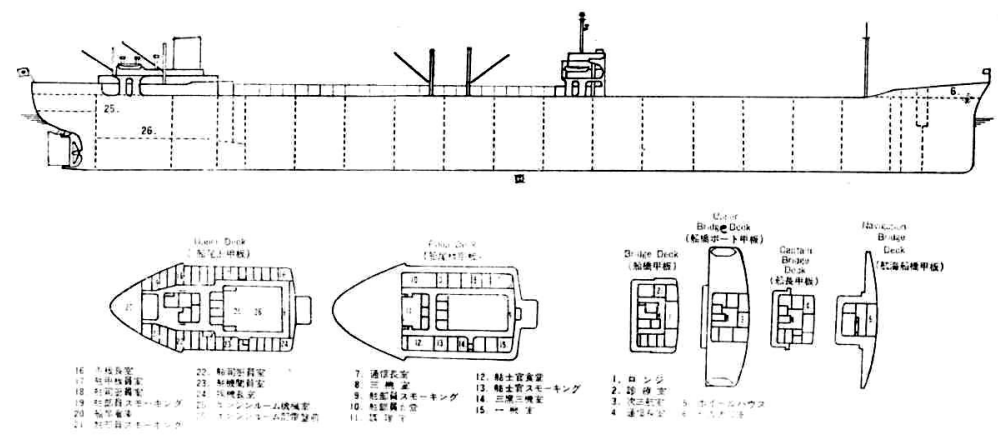

図 1 日章丸の外観図

（1）機械化が進んだ結果，筋的作業が減少した反面， 精神作業が多くなり，精神疲学が増大した。

(2) 運航能率の向上に伴ない, 碇泊日数が極端に減少 した．そのため乘組員は有給休睱による下船までの期間 陸上から隔離された船内生活を送ることを強いられてい る.

（3）居住設備は向上したとはいうものの, 物理的, 精 神的居住環境はむしろ低下しているものさえある．例え ば振動, 騒音が激しいこと, 極端な人員削減による疎外 感等である.

そこで乗組員の船内生活を快適ならしめ，モラールを 高めるためには居住環境は如何にあるべきかを人間工学 的方面から究明し，改善策を提案することを目的とする

\section{1-2. ペルシャ湾航路タンカーに関する調查}

人間工学の立場からみると, 船舶については, 種々の

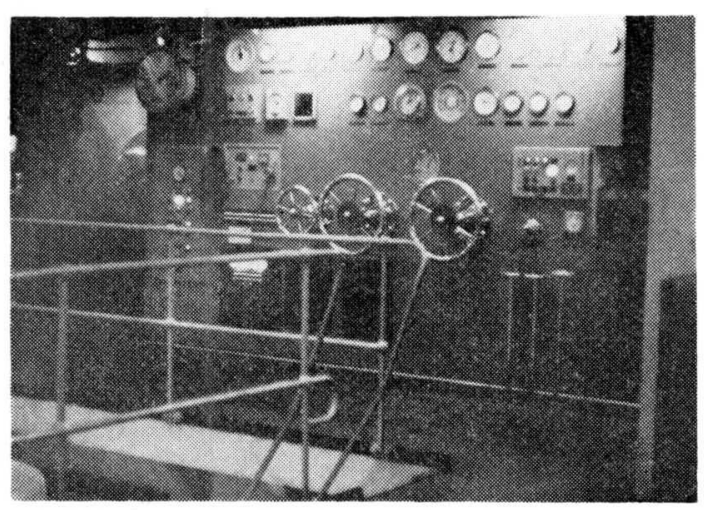

（写真）日章丸の制衔室

\section{調查・测定項目}

1. 船内居住区・作業区における照明・色彩に関する調㚗 2. 船内居住区・作業町に打ける騒音・振動に関する調査 3. 船内居住区・作業区における温度・湿度に関する調査 4. 乗組員の居住・作業環境に関するアンケート調査 5. 乗組員の船内生活全般に関するアンケート調查 6. その他船内環境・船内生活に関する総合調査

問題があるが，船舶の種類により，問題になるところも 多少相異する．われわれはわが国産業のエネルギー資源 として重要な石油の輸送船, ペルシャ湾航路に就航する タンカーについて調查を行なった.

ペルシャ湾航路のタンカーは普通, 数万トンから20万 トンの大型船であり, 速度も大で, 操船も漸次自働化の 傾问にある．日本からペルシャ湾沿岸の産油地まで往復 約35日の航海であるが，熱帯を通過するため，気候の変 化が大きい，最近, 船内の公室, 居室に冷房を 実施するようになってから, 温度的環境は改善 されつつあるが, 騒音, 振動その他の居住設備 では未だ改善すべき数多の問題を蔵している.

タンカーは往復約35日の航海中, 目的地以外 に寄港しないから，乗組員は殆んど船内で過ご さなけ机ばならない，目的地では石油を積載 (パイプで船内タンクへ石油を吸入する)する 時間と港内の着棧待機時間の合計が目的地での 滞在時間であるが普通約 1 日である. 内地碇泊 中は石油の陸揚（石油をパイプを通じ陸上の夕 ンクへ導入する）と航海に必要な物資の積込に 要する時間が碇泊時間であり, 普通約 2 日間で ある. 内地碇泊中一部の乗組員は休養をとるこ 
要する時間が碇泊時間であり, 普通約 2 日間である。内 地碇泊中一部の乗組凅は休養をとることが山来るが，他 の乗組員は作業に繁忙を極める.タンカーの運航状態は いわゆるピストン運転である。したがって乘組員の生活 は陸上の産業労働者と著るしく生活形態が巽なり, 人間 生活の上からみて種々の問題を包含する.

わ狄わはタンカー乗組員の居住環境, 作業と生活の 全般にわたり，調査を行ない，それらの結果に基ついて 改善方法を考究したい，すなわち，少しでも乘組員の船 内生活を快適にし，これによって志気を高め，運行能率 を问上させるとともに，乘組員が悦んで船内の作業と生 活をなし得るよう人間工学の立場より改善策を考究せん とするものである。

そこで事例研究による大型タンカー船内居住環境に関 する人間工学的分析の一環として, 現在運航中のペルシ ヤ湾航路大型タンカーーに乗船して各種の測定を行った。 対象船（図1参照）および調查項目は表の通りである。

日章丸の性能 船体の長さ : $291.00 \mathrm{~m}$ 船体の幅 : 43.00 $m$ 深さ: $22.20 m$ 吃水 $: 16.50 m$ 載貨重量トン $(\mathrm{D} / \mathrm{W})$ $: 132.33 \mathrm{~K} / \mathrm{T}$ 速力 $: 18.11$ ノット 乗組員 : 44名

調查時: 第 40 次航海（昭和 41 年 12 月 24 日 昭和 42 年 1 月 26 日）

第 42 次航海（昭和 42 年 3 月 11 日 昭和 42 年 4 月 15日)

以上のような調査項目のうち，本稿では照明・色彩・ 騒音・振動扰よび温・湿度条件について, 観測值の分析 を行ない，あわせて船内居住環境打よび作業環境の検討 を行なったが，そのうちの一部を報告するものである.

なお，項目(6)の乗組員の船内生话に関するアンケート 調査の結果については, 機会を改めて分析の予定である

\section{2. 色彩・照明条件の検討}

\section{2-1. 照明調查}

（1）調査日時 1967 年 1 月 5 日 1月 12 日，午後 2 時 $\sim 4$ 時㧍よび午後 7 時 $９$ 時

（2）航海海域 アラビア海，オーマン沙，ペルシャ湾

（3）天候 晴

(4) 船内調查筒所 同船内の居住区, 制御区, 生活区

(5) 使用計器 東芝照度計 7 号

(6) 調查結果

船室外昼光照度一船室外甲板上の直射昼光照度は5000 $1 \mathrm{x}$ 以上で, 東芝照度計 7 号では測定不能であった。

船室内の照明 : 昼間抢よび夜間における船内の居住区

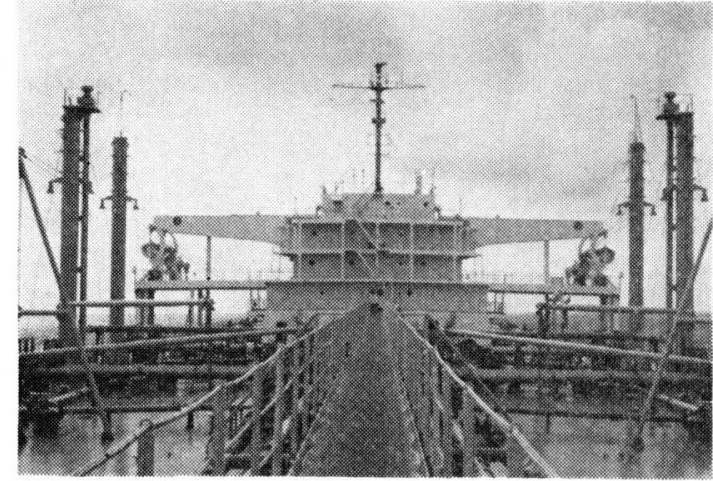

[写真]日章丸の甲板

制御区，生活区の照度を表示すれば表1の通りである。

光源：光源は白熱電灯を主体とするが，公室（集会室 食堂, 喫煙室等) では螢光灯を用いている.

照明器具 : 照明器具は一般にガラスのグローブのつい たものを使用しているが，船員の居住区では乳白色のグ ローブを, 制御区，生活区では無色透明のグローブを使 用，また局部照明として机にはスタンドを，鏡にはシリ ンダー型アクリル・カダー付の照明器具, ベッドの側壁 には乳白色カバー付ベッドランプを使用している．

照度一昼間は船室の円空を通して昼光が入射するため 概致 J I S の基準照度以上になっているが，夜間は人工 照明のみによるため照度低く，基準照度に達しない筒所 が多い，昼間，基準照度に達していない船室は船主室， 無線室炊事場，浴室，洗濯室等であり，その他は基準以 トである。

夜間における室内照明は人工照明のみによるが，基準 照度に達しないものが多い，基準照度以上のものは次の 諸室である。

集会室, 士官室, 部員宾, 部員食堂, 部員喫煙室, 部 員洗面所, 海図室, シャィロ室, これ以外の室の照度は

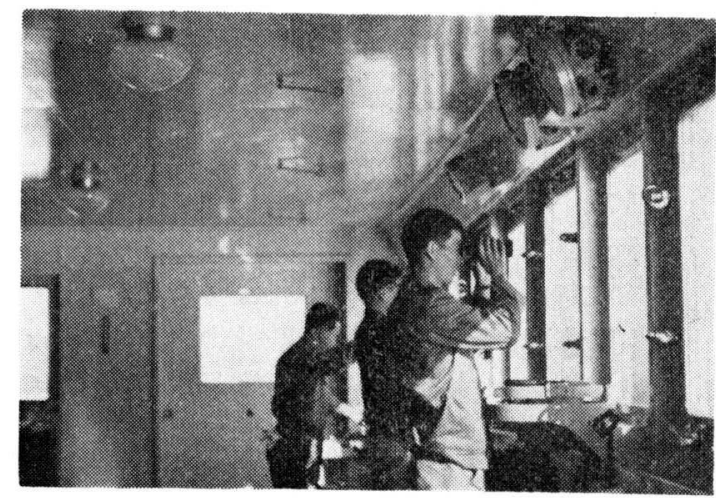

[写真] 日章丸の船橋 
表 1 船内主要個所室内照度 (単位 iux)

\begin{tabular}{|c|c|c|c|c|c|}
\hline 船内测定個师 & 昼 & 依 & 船内測定個汧 & 䭪 & 依 \\
\hline $\begin{array}{l}\text { 居住区 } \\
\text { 口ンシ } \\
\text { 士官食堂 } \\
\text { 部員膛 } \\
\text { 船主室 } \\
\text { 船長公室 } \\
\text { 船長寝室 } \\
\text { サロン士官室 } \\
\text { 士官室 } \\
\text { 職長室 } \\
\text { 部員室(個室) } \\
\text { "( } 2 \text { (室) } \\
\text { 士官喫煙室 } \\
\text { 部員喫煙室 }\end{array}$ & $\begin{array}{l}200 \\
170 \\
200 \\
120 \\
170(300) \\
140 \\
180(280) \\
140 \\
100(140) \\
50 \\
40 \\
70 \\
100\end{array}$ & \begin{tabular}{|l}
160 \\
165 \\
130 \\
25 \\
$100(140)$ \\
60 \\
$60(60)$ \\
$60(85)$ \\
$65(80)$ \\
40 \\
30 \\
60 \\
100
\end{tabular} & $\begin{array}{l}\text { 診療室 } \\
\text { 病室 } \\
\text { 通路 } \\
\text { 制御区 } \\
\text { 操舵室 } \\
\text { 海区室 } \\
\text { 無線室 } \\
\text { 涪社 } \\
\text { 生活区 } \\
\text { 調理室 } \\
\text { 配膳室 } \\
\text { 部員洗面所 } \\
\text { 便所 } \\
\text { 浴室 }\end{array}$ & $\begin{array}{l}100 \\
100 \\
10 \\
\\
800 \\
130 \\
160(180) \\
130 \\
\\
30 \\
30 \\
30 \\
30 \\
30\end{array}$ & $\begin{array}{l}65 \\
80 \\
5 \\
\\
0 \\
0(110) \\
30(40) \\
80 \\
\\
20 \\
20 \\
20 \\
20 \\
20\end{array}$ \\
\hline
\end{tabular}

（）内はスタンドによる局部照明の照度

全て基準に達しない。航内の照度基準は陸上における照 度基準より一般に低いが，本調査の結果は船内照度基準 にも達しないものが多い.

卓上灯，鏡灯等の照明器其はより効率のよいものと交 換すれば，照度は向上する. 光源を白熱灯より螢光灯に 改め,これに応じた照明器具を使えば簡単に解決される.

ベッドランプは単に睡眠するだけに用いるならば現状 でよいが，船員の多くはベッドに横臥しながら読書する ので, 読書に必要な照度を必要とする. 現在は枕元で10 〜 40 lx, なかでも $201 \mathrm{~lx}$ が最も多い、読書には150〜300lx （平均 $200 \mathrm{~lx}$ ）必要である。また海应室，無線室等の人 工照明は照度を上昇する必要がある。

一般に生活区の照明は貧弱であって夜間照度は極めて 低い. 白熱灯を螢光灯に切替えるならば，等しい電力で 相当高い照度を得ることが出来る. 炊事場, 配膳室等は 衛生上の見地からみて, 明視を必要とするので照明をよ くしなければならない。

（7）照明調査結果の要約 一般に夜間の人工照明の照 度が低い。これは白熱灯を螢光灯に替えることによって 照度を上げることが出来るので, 改善は容易である.

\section{2-2. 色彩調查}

（1）調査日時 1967 年 1 月 16 日午後 2 時〜 4 時

(2) 航海海域 アラビア海

（3）天候 晴

（4）船内調査個所 同船内の居住区, 制御区, 生活区

（5）調查方法 日本色彩社，産業用標準色票（マンセ ル方式）により色合わせを行ない, 調查した。

（6）調查結果 いま居住区，制御区，生活区につい て，色彩を調查した結果は次の通りである.

居住区の天井は全部白（9.3N）である．壁は公室お
よび船主室, 船長室機関長室ではY $\mathrm{R}$ 系を, 士:官室部員室, 診療室等で はY G (7.5Y G9/2) を使用してい る。床は R(2.5R3/5), 扉はB G (10 B G6/1), 家具名 B G (10B G6/1) である、机は灭色 $(7 \mathrm{~N}$ または $8 \mathrm{~N})$ である。

通路の天扸抢よび壁は彩度の低い $\mathrm{Y}(5 \mathrm{Y} 9 / 2)$ ，床はR (2.5R3/4)， 屝はB G (10 B G6/1) である.

制御区の天井は操舵室(7.5G9/1) 以外は白 $(9.3 \mathrm{~N})$ 壁は $\mathrm{G}(7.3 \mathrm{G} 9 / 1)$ ， 巾木はB G (10 B G6/1)，床は操舵 室が $\mathrm{G}(2.5 \mathrm{G} 6 / 2)$ ，無線室は B G (7.5B G 5/2), 海図室, ジャイロ室等はR $(2.5 \mathrm{R} 3 / 5)$, 扉，家具はB G（10B G6/1）を使用している.

生活区の天井および壁は白 $(9.3 \mathrm{~N})$ ， 巾木は炊事室， 配膳室 $(10 \mathrm{~B} \mathrm{G} 6 / 1)$ 以外洗面所, 便所, 浴室, 洗濯室 等で黒 $(1.5 \mathrm{~N})$ を使用し，床には白 $(8.5 \mathrm{~N})$ ，屝には B G (10B G6/1) を使用している.

制御区で使用せられる航海計器類，無線機械類は $\mathrm{G}$ 系 統 $(2.5 \mathrm{G} 7 / 2)$ である。

炊事室, 配膳室等の各種の器具・仆器には白 $(9.3 \mathrm{~N})$ が多く用いられている.

（7）色彩調査結果の要約 色彩計画は船内のみならず 船の外装部すなわち，船体の色彩計画全体が優れている と思う. 快適な視覚環境を形成していると考える.

\section{3. 騒音条件の検討}

\section{3-1. 測定目的}

船舶の騒音の乗組員に与える影響は心身共に無視でき ないものがあり, 従来も各種の研究が行なわれている. これらの研究は主として船舶騒音を物理的に詳細に測定 し, 測定結果より聴覚の特性と対応した種々の指数, た とえば SIL, NC, NCA, NC-dB, NRN などを算出し, これについて許容值その他の考察を行なったものが多い (中野, 1965 ; 神田, 1964). 一方, 物理測定は行なわ ず，アンケート調查によって乗組員の騒音はじめ船舶環 境に対する意見（主として苦情）を求めたものもある.

われわれの騒音の測定は，一才では騒音を物理的に組 織的かつ出来る限り精密にとらえると同時に, 他大では Semantic Differential や意見調查など, 乗組員に主钼 的評定を求め, 物理量と心理量との対応関係を求める. 
この結果から船舶の許容値に対する一つの提案を行なう と共に主観量と対応のよい船舶騒音の物理量測定方法の 指数の算出について考察を行ない，さらに船舶騒音の主 観的測定法についても提案を試みたい。このような目的 のもとに一連の測定を行なった。

\section{3-2. 物理的測定}

（1）測定対象船：出光タンカー日章丸

(2) 測定器: 騒音計 リオン NA-02 型 2 台, リオン $\mathrm{NA}-07 \mathrm{~A}$ 型 1 台, 周波数分析器 リオン $\mathrm{S} \mathrm{A}-55$ 型, テープレコーダ ソニー7772 J 型

（3）測定項目および方法：i）船内全居室に対し，A特 性を用いて25回測定. ii) 船内主要26力所を, C, B, A 3 特性について， 5 秒間隔 25 回測定. なおここの data は, Semantic Differentialによる 主観量と対応づける iii) 後部居室 8 力所について, C, B, Aの 3 特性扰よび オクターブフィルターの 9 帯域全部について 5 秒間隔で 各50回づつ測定. また, 同時に騒音のステレオ録音を行 なう。この録音を用いて後に実験室的研究を行ない，船 舶騒音の大きさおよび喧騒度の正確な結果を求める予定 である。また iii）のdata は ii）の簡易な測定結果の 信頼性の確認および, 将来, 聴覚と対応づける実験の基 礎資料として用いる予定である。

\section{3-3. 主観的測定}

\section{1. 船内騷音の音色評定}

(1) 目的：複数の評定者によって船内各箇所をSemantic Differential（S.D.法）を用いて主観評定し，物理 測定の結果と対応づける. 評定者は船内各箇所の騒音に ついて, 評定用紙を用いて評定を行なう。評定尺度は北 村，難波ら（1963）の資料を参照して選択した。

（2）方法：i）評定者(11名) はなるべく全乗組員を代 表しうるように甲板・機関・事務の各職務別, 前部およ び後部居住区別, 職員・罪員別に考慮して各層より選択 した，評定場所は予備調査により26䇢所を設定, 職場お よび居住区を含み、レベルの低いところから極めて高い 場所まで含めてある. 評定用紙記入の要領並びに注意事 項を, 評定用紙と共に各評定者に配布し, 各評定場所に 案内して評定を行なった。評定は往航時, 帰航時に各一 回実施.

（3）評定日：往航時一炤和 42 年 3 月 19 日 帰航時一昭 和 42 年 4 月 9 日

(4) 結果と考察 結果の一例(往航時)を図 2 に示す. 往航, 帰航時の評定結果を通覽して次の傾向が伺水れた。

$\mathrm{A}$ 特性による测定值が，50 52ホンであれば，大体静

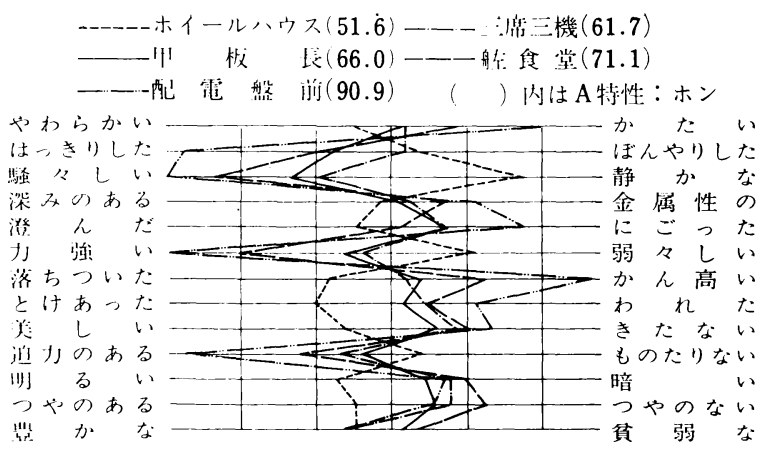

図 2 船内騒音の音色評定

かな環境と感じられ，55ホン前後であれば，まず可もな し不可もなしといった状態で, 生活する上に全く支障が ないといってよさそうである（NRN44６0）．60６4ホ ン $(\mathrm{A})$ になると, “騒々しく”感じられ始め，65ホン $(\mathrm{A})$ を越えると，“騒々しい”“力強い”“迫力”の尺度值 が高くなると共に“にごった”“きたない”等，音色の 悪化がみられる (NRN58〜64)，さらに，70ホン(A)を 越えると，“騒々しさ”“力強さ”“迫力” の尺度值が 更に高くなり，“きたない”“にごった”等，音色が悪く なると共に、“はっきりした”“かたい”“かん高い”“金 属性” の不快な音色となる（NRN64～69)，80ホンを越 えると不快感は極度に高くなり, 生活に不適当であるこ とはいうまでもない。このレベル付近になると聴力損失 の心配がでてくる（NRN81〜87）。なお，各測定点毎に 往航時の評定と帰航時の評定を比較すると，やはりレべ ルが高いのを反映してか，帰航時の評定の方が，悪い評 定を得ている.

\section{2. 騒音・振動に関する意見調査}

(1) 目的：上記の音色評定は, 各評定点における騒音 の感じを瞬間的にとらえたものであって，そこで長時間 , 生活し作業している場合の資料ではない. 従って, こ の騒音下で暮している人々にとって，その騒音が日常生 活の上にどのような影響を与えているのかを求めている ものではない，そこで, 騒音ならびに振動の船内居住生 活におよぼす影響を知る目的で, 各自の居室について以 下のアンケートを行ない, 物理的測定の結果およびS.D. 法による騒音評価と対応づけて考察する．今回の報告は 主として騒音を中心に分析する，振動に関しては，第 2 報にゆずりたい．

（2）万法：全乘組員に調查用紙を配布し，留置式で記 入を求めた.

(3) 調查日：昭和 42 年 4 月 10 日配布, 同月 13 日回収

(4) 結果と考察 : 問 1 この設問は43の質問文より構 
成されている。 その内签を分類すると, 乗組員の居室騒 音に対する綜合的評価，乘組員が船のどのような種類の 騒音をうるさく感じているのか，騒音に対する慣れ，態 度，騒音と身体条件との関係，騒音と睡眠の関係，たと え何らかの代償を払っても居室を代りたいと思っている かどうか，騒音と読書・考え事・会話との関係などの問 題について卒直な意見を求めたものである.

単純集計の結果は明瞭な傾向が得られなかったが，騷 音レベル別層別分析した結果，大要つぎの傾向が得られ た.すなわち59ホン(A)以下では居室として問題はない. 一方70ホン(A)を越えると，これは居室として，精神的 にも身体的にも問題があるのではないかと思われる，従 って60〜69ホン(A)の間が許容領域ということになるが S. D. 法の絬果などからみて,やはり少くとも65ホン (A) 以下に押えることが望ましいのではないかと思われる。

問 2 この設問は，他者（第三者）の騒音・振動に対 する苦情を尋㸚るという形式をとっている。 この形式を とることによって，自己の不満としては表現し難いこと も知ることができる。

さて，眠れないといった苦情が上位を占め，レベル別 に分析しても，項目 1（騒音がうるさいのでよく眠れな い）の場合には，レベルが上がるにつれて反応数も増加 し，70ホン（A）を越えると全員（100\%）が肯定してい る.同様に項目 7 (騒音がうるさいので部屋を代りたい) 表 2 騒音各指数と音色評定と相関係数

\begin{tabular}{|c|c|c|c|c|c|}
\hline & A & $\mathrm{B}$ & $\mathrm{C}$ & N R N & S I L \\
\hline A & - & $\cdot 952$ & $\cdot 882$ & . 952 & - 971 \\
\hline $\mathrm{B}$ & $\cdot 952$ & - & . 975 & $\cdot 921$ & - 962 \\
\hline $\mathrm{C}$ & - 882 & $\cdot 975$ & - & - 839 & $\cdot 923$ \\
\hline N R N & - 952 & . 921 & $\cdot 839$ & - & - 901 \\
\hline S I L & - 971 & $\cdot 962$ & - 923 & - 901 & - \\
\hline か た い一やわらかい & $\cdot 955$ & $\cdot 954$ & - 909 & $\cdot 900$ & - 950 \\
\hline にごった 一澄んだ & - 922 & $\cdot 904$ & $\cdot 846$ & $\cdot 847$ & $\cdot 920$ \\
\hline かん高い一落ちついた & $\cdot 916$ & $\cdot 867$ & - 802 & $\cdot 832$ & - 901 \\
\hline 力強い 一-弱々しい & $\cdot 930$ & $\cdot 912$ & - 957 & $\cdot 850$ & $\cdot 936$ \\
\hline 迫力のある—もの足りない & $\cdot 927$ & $\cdot 876$ & - 824 & $\cdot 856$ & - 915 \\
\hline 騒々しい——静かな & $\cdot 904$ & $\cdot 894$ & $\cdot 848$ & $\cdot 841$ & $\cdot 909$ \\
\hline はっきりした——ほんやりした & $\cdot 856$ & $\cdot 763$ & $\cdot 655$ & $\cdot 811$ & $\cdot 813$ \\
\hline 暗い —明るい & $\cdot 736$ & $\cdot 765$ & $\cdot 752$ & - 641 & - 769 \\
\hline ——深みのある & $\cdot 578$ & - 542 & - 532 & $\cdot 507$ & $\cdot 573$ \\
\hline きたない 一美しい & $\cdot 809$ & $\cdot 813$ & $\cdot 789$ & $\cdot 721$ & $\cdot 855$ \\
\hline つゃのない—つやのある & $\cdot 669$ & $\cdot 732$ & $\cdot 725$ & $\cdot 592$ & • 693 \\
\hline われた 一とけあった & $\cdot 720$ & $\cdot 678$ & $\cdot 624$ & $\cdot 627$ & $\cdot 737$ \\
\hline 一一貧弱な & $\cdot 172$ & $\cdot 020$ & $\cdot 042$ & $\cdot 169$ & $\cdot 083$ \\
\hline
\end{tabular}

表中のS.D の形容詞尺度は相関保数が、の佔になるよう形容詞対の位置を変更してある．
についても, レベルが上がるにつれて反応数が増加し， やはり70ホン(A)以上では 100\%が肯定している. 50ホ ン(A)以下では非常に少ない（14.3\%)。このように問 2 の結果は閂 1 のそれを蓑書きしているようである。

問 3 この設問は，改善を希望する環境条件を尋ねた ものである.

騒音レベルが50(A)以下であると，振動や騒音の軽減 よりも，むしろ冷暖房の調節や照明の改善が要求されて いる. 60〜64ホン(A)では, 騒音・振動の改善が 2,3 位に上がっているが，しかし照明の改善が第 1 にあげら れている，ところが，65ホン(A)以上になると，振動・ 騒音が $1 ， 2$ 位を占めている.

この結果よりみても, やはり59ホン(A)以下では問題 はなく, 60〜64ホン (A)程度から騒音の影響が出始め, 65ホン $(\mathrm{A})$ 以上では生活の妨げになっていることが推察 できる.

\section{3-4. 物理量から算出した種々の評価数 (NRN, SIL, sone, phon)と S.D. 法との関連}

以上の主観的測定の結果と物理量とを対応うけて，船 舶騒音に適切な評価数の選定を行なうことができる.

さて，騒音の物理的測定はすでに 3-2 で述べたように 騒音計の C, B , A 3 特性で测定すると共に，才 クターブ・フィルターによる周波数分析を行な った.この周波数分析の結果より, NRN, NC. SIL等の騒音の評価值および sone, phon 等の 騒音の大きさを算计した。なお，ここで，A， B, C 各特性および NRN, SIL, sone, phon 等の数值は, 物理量から感覚量を推定するべく 求められたものではあるが, 感覚量そのもので はない，そこでこれらの数值の総称として，仮 に騒音各指数と呼ぶことにする。

これら騒音各指数間の相互相関係数（表 2 ） をみると，全体に高いことが分る。このこと は，いずれの指数も同じものを指示しているこ とを示唆している．换言すれば 1 つの指数のみ で, 他の指数を代表しうる可能性のあることを 意味する.これらの指数の中で, 特に $\mathrm{A}$ 特性に よる測定值が他の指数との相関が高い. 表から も明らかなように, 騒音各指数と S.D. 法の尺 度值の間にも高い相関関係のあることが分る. 特に A 特性と S . D. 法の尺度值の間の相関が高 い.これらの結果は, $\mathrm{A}$ 特性の測定值をもっ 
て，他の指数の代表としうることを示唆している．

S. D. 法の尺度值の中で, 騒音各指数との相関の高い のは, “かたい一やわらかい”,“にごった一澄んだ”,“か ん高い一落ち着いた”, “力強い一弱々しい”,“迫力のある 一もの足りない”,“騒々しい一静かな”などで，“豊かな 一負弱な”は, 相関係数が目立って低い.

次に， S. D. 法の尺度值と A 特性の関係について, 散 布図を作って考察してみると, 散布が尺度值 1 付近から 7 付近に及ぶものと散布の範囲が狭いもの, 散布が 4 付 近に固まるもののあることが分った．もちろん，散布が 1 から 7 に及び,かつ相関係数の高い尺度が, 騒音の物理 的変化を敏感にとらえうる尺度ということができよう。 このような観点よりみて，特に“やわらかい一かたい”

“騒々しい一静かな”の両尺度は騒音の評定に適当な尺 度ではないかと思われる。

結論として, 騒音の物理的測定は騒音計の $\mathrm{A}$ 特性を用 い, S.D. 法による評定は“やわらかい一かたい”“騒々 しい一静かな”の 2 本の尺度だけでょいということにな る.もちろん, この結論は日章丸と類似したタイプの船 舶騒音に限ることを断っておかねばならない.

\section{3-5. 船舶騒音の許容值}

現在までに得た資料のみで船舶騒音の許容值を決定す ることは,もちろん無謀である.しかし, 得た資料の範囲 内で一つのケースとして許容值について考えてみよう.

この際に参考になるものが, 騒音各指数について求めら れている既存の基準值であるが，これを船舶の居室に適 用した場合，この基準は船舶にとっては低すぎるようで ある。（例, 住宅は $\mathrm{A}$ 特性で40ホン, 寝室はNCで30, NRN30というように低く，本船の場合，この基準を下 廻る居室はない)

そこで, S.D.法打よびアンケートの結果より推定し てみて, 居室は60ホン $(\mathrm{A})$ 以下であればまず良好，65木 ン(A)までは何とか許容できる。65ン (A)を越えると 不快感を与え易く, 70ホン (A)以上は不適当といえよう 公室の場合は，SI Lが50以下であれば， $6 \mathrm{ft}$ 離れて普 通の声で会話できるので, まず問題はないといえよう(本 船では, S I L 50 以下の時, 騒音レベル 67 68ホン程 度であるので, 喧騒度の面からいっても, 公室であれば 我慢できるであろう)。作業場も, 煊騒度および会話の 面からいって，70ホン(A)以下に押えたいところである が, 本船のような周波数特性の騒音の場合, 聴力保護の 点から考えて, 上限は80ホン(A)以下にすべきであろう.

\section{4. 温湿度条件の検討}

ペルシャ湾航路は, 我国の温帯地域から, 南支那海, マラッカ海峡, インド洋の熱帯の水域を経てペルシャ湾 の亜熱帯乾燥地帯に航海するものであるため, 気候の激 変が著るしく, 航海中, 乗組員の中には身体の不調を訴 える者が多く, 久保の研究によれば, 持続的な高温の作 用によって水血症を来たしたり, 血圧低下, 尿比重低下 が見られることが明きらかにされている. その他, 高温 のための体重減少, 倦点感, 頭痛感の訴えはよくなされ るところでありこうした事情を反映して国際労働条約 に基づく設備の改善が行なわれる一方, ペルシャ湾航路 のタンカーには冷房設備が義務づけられたり, 高温下で の作業規制が䘕なわれたりしている.しかしながら、こ れらの冷房設備は船内の居住区, 作業区のみであって, 甲板作業は炎天下で行なわざるを得ない時もあるし，機 関室, 調理室等は高温から逃れることはできない.

そこで, 次に環境条件の検討の一環として, 温熱条件 をとりあげ，分析するものである。

\section{4-1. 方 法}

船内主要個所において, 温度, 湿度の定時測定を行な い, 更に乗組員全員にアンケート用紙を配布し, 居室, 作業区の温湿度条件について回答を求めた。

(1) 温湿度測定器具 アースマン通風式温湿度計, 乾 湿球温度計, 最高最低温度計, 毛髪式湿度計等.

（2）測定場所 表 3 に示す 8 力所の他船内主要 18 力所

（3）測定日時 日章丸第42次航（昭和 42 年 3 月11日～ 4 月15日), 定時測定時刻, 午前10時 (9.30 10.30)

\section{4-2. 結果および考察}

各測定場所にける観測值から，1航海約35日間の平均 值および標準偏差值を算出したものが表 3 である. 対象 船はミドルブリッヂ方式のタンカーであり，居住区は前 部と後部に分かれている. 後部エンジンハウスは, エン ジンという熱源のため, 全般に温度が高くなっており, 居室で平均 $25^{\circ} \mathrm{C}$ 前後, 通路で $30^{\circ} \mathrm{C}$ 前後となっている. しかし, これは定時測定の温度であって, 最高温度の平 均値となると, 1 標準偏差内の值で, 居室で $23^{\circ} \mathrm{C}$, 通

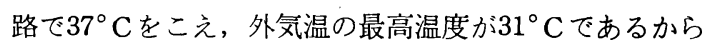
後部ハウスは非常に高温といえる。これに反し, 前部ブ リッヂハウスでは, 総じて温度は低く航海中の経験では ロンジ等はむしろ寒く感じられる時もあった，比較的高 温の後部居室といよども冷房設備が設置されることによ り条件は緩和されている。

図 3 は航海中の温度の変化を, 戸外と, 居室, 作業区 の一例として各々, 甲板長室, のである. 外気温は出港 
表 3 船内主要個所温湿度平均值

\begin{tabular}{|c|c|c|c|c|c|c|c|c|}
\hline \multirow{2}{*}{ 測 定 場 所 } & \multicolumn{2}{|c|}{$\frac{\text { 最高温度 }}{{ }^{\circ} \mathrm{C}}$} & \multicolumn{2}{|c|}{ 最低湿度 } & \multicolumn{2}{|c|}{ 温度 (10時) } & \multicolumn{2}{|c|}{ 湿度 (10時) } \\
\hline & 平均 & $\mathrm{S} \mathrm{D}$ & 平均 & $\mathrm{S} \mathrm{D}$ & 平均 & S D & 平均 & $\mathrm{S} \mathrm{D}$ \\
\hline 户外 & 27.8 & 3.2 & 23.2 & 4.4 & 25.0 & 4.1 & 72.2 & 14.6 \\
\hline ロンジ（前部） & 23.4 & 2.4 & 20.1 & 2.3 & 22.0 & 2.9 & 58.7 & 10.6 \\
\hline 航海練習生室(前部) & 27.8 & 1.3 & 24.2 & 1.8 & 24.7 & 2.0 & 53.7 & 8.7 \\
\hline 通路-3(後部, 左舷) & 35.2 & 1.9 & 29.7 & 2.3 & 29.0 & 3.3 & 49.1 & 10.8 \\
\hline 三等機関士室(後部) & 27.0 & 2.4 & 26.6 & 2.3 & 24.8 & 3.1 & 52.1 & 11.4 \\
\hline 調理室（後部） & 38.5 & 3.3 & 27.9 & 3.4 & 29.8 & 3.4 & 60.2 & 12.9 \\
\hline 甲板長室（後部） & 29.3 & 2.6 & 24.2 & 2.6 & 26.9 & 3.0 & 47.7 & 10.8 \\
\hline 機関室（後部） & 36.1 & 3.2 & 33.8 & 5.2 & 33.1 & 3.9 & 47.9 & 13.3 \\
\hline
\end{tabular}

少し暑いと感ずる者10名, 非常に 暑いと感ずる者 4 名で計 $93 \% に も$ 及ふ者が暑さを訴えている。調理 室でも事情は同様であって，7名 中 6 名までが非常に暑いと答えて いる，徒ってこれらの部署での作 業には設備として更に強力な冷房 装置が必要とされよう。神田によ れば $85 \%$ 以上の人が快適と感ずる 感覚温度は, 冬 $18.3 \sim 21.1^{\circ} \mathrm{C}$, 夏20.5 22. $8^{\circ} \mathrm{C}$ であり, 各種作業 の至適温度は $13 \sim 18^{\circ} \mathrm{C}$, 筋的作業 で $10.0 \sim 17^{\circ} \mathrm{C}$ であるのを見れば

後数日にして急上昇し, $25^{\circ} \sim 31^{\circ} \mathrm{C}$ となり, ペルシャ湾 に入る頃から又降下する。そして，こうした温度変化を 往航帰航と 2 度繰り返すことになる，愿室は熱帯水域航 海中, すなわち，東支那海からアラビア海までの約 10 日 閂は，船内に冷房の空気調幯が行われるため， $26^{\circ} \mathrm{C}$ 前 後を保っている. 日本近海, ペルシャ湾航行時は冷房が 行なわれないため室内温度はやや高めとなるが，通風換 気は常時行なわれており, 結局, 居室に限ると, 温度条 件は快適とまでは行かなくとも，暑さに悩まされること はない．仮に暑い時があっも冷房ダクトの方向を変え調 䬦することにより，暑さは容易にしのぎ得るといえよう。

しかしながら問題はむしろ作業区に残されているので あって, 表 3 に目立つことは高温作業場として調理室と 機関室があげられることである，前者では平均 $30^{\circ} \mathrm{C}$, 最 高 $38^{\circ} \mathrm{C}$, 後者では平均 $33^{\circ} \mathrm{C}$, 最高温度の平均値 $36^{\circ} \mathrm{C}, 1$ 標準偏差内の最高温度では $39^{\circ} \mathrm{C}$ を指すにいたり, 各個

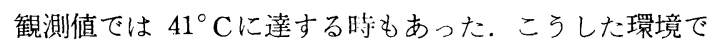
の作業は重労働であり，アンケート調査でも機関室では

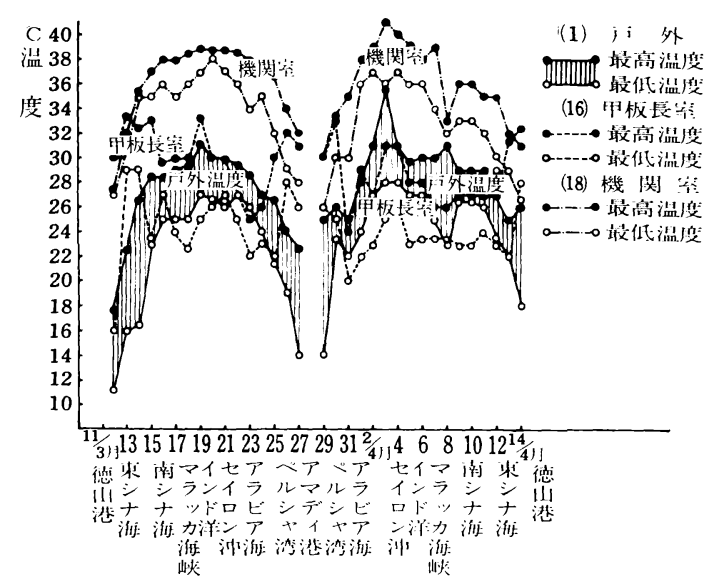

図 3 気温の変化
船内のこれらの作業区は非常に高温と言わ稀ばならない そして，湿度に関しても，表 3 のごとく全般には50\%前 後に分布しているが，その主観的評価では，機関室，調 理室においてのみじめじめしているという反応が出現し これらの 2 作業区は温湿度画面加至適条件とは言い難 いものとなっている.

機関室では計器盤, 操作盤前は空気調節され, 冷気が 吹きつけられているが，その近傍においてすら図 3 のご とく熱带水域通過時は $35^{\circ} \mathrm{C}$ を越えており, 計器盤, 操 作盤前を離れると更に高温となろう。

\section{交献}

1) 神田寛：ペルシャ湾航路タンカーにおける室内気候 について, 日本航海学会第18回講演会資料集, $25 \sim 31$ 1957

2 ) 神田寬: 船舶の居住性能, 労働科学, 第40巻第 9 号 427 438, 1964

3 ）神田寬：船舶の居住性能一人間工学的研究一, 成山 堂書店, 1964

4 ) 北村音壱, 飯田茂隆, 佐々木実, 難波精一郎：音の 研究（11）音色評定尺度の信賴性と妥当性について, 音響学会講演論文集135～136, 1963

5 ）久我正男：ペルシャ湾航路タンカー船員の血液およ び求よりみた暑熱の影響について, 労働科学, 第35巻 第 4 号, 342 350, 1959

6 ）久我正男: 酷熱ペルシャ湾航路タンカー機関員の二 三の生理機能について, 学働科学, 第35巻第 4 号, 351 $\sim 365,1959$

7 ）中野有朋：舵の騒音について, 造船協会論文集, 117 号, 316 329, 1965

8）日本音響材料協会編：騒音対策ハンドブック，技報 堂, 1965 